\title{
Study of the electrical resistance, electrical strength and angle of separation of rice seeds from the drum surface
}

\author{
Gulnoz Aslanova, Makhbuba Charieva , Solikha Shoyimova, Anvar Sirojov, and Shokhruh \\ Pirnazarov \\ Bukhara Engineering-Technological Institute, Bukhara, Uzbekistan
}

\begin{abstract}
The article provides information on the "Dielectric" device for sorting seeds of agricultural crops and the results of theoretical research on seed sorting. The results of theoretical experiments showed that the diameter and number of turns of the working body of the device for sorting rice seeds in the "Dielectric" device, the expected result can be achieved by applying high voltage to the electrodes with opposite signals.
\end{abstract}

\section{Introduction}

According to the information service of the Ministry of Agriculture of the Republic of Uzbekistan, based on the proposal to establish rice "Cluster" enterprises in the Republic from 2020 [1]. To cultivate high-quality rice seeds, prepare them for sowing, and ensure the supply of processed rice products to domestic and foreign markets, the country is required to conduct research.

With this in mind, the recently established Uzbeksholichilik Association is expected to develop innovatively through the supply of early and middle-aged, disease-resistant rice seeds to farmers, farms, and the supply of rice products to the population export, introduction of energy, and resource-saving technologies. It is known from research that the result can be achieved [2,3].

As a result of many years of research conducted in recent years, the Research Institute of Agricultural Mechanization (ICMIT), under the leadership of A.Rosaboev, Bukhara Institute of Engineering and Technology (Bukhara Institute of Technology), in collaboration with independent researcher S.P.Shoyimova created an experimental laboratory version of the device for electric sorting of rice seeds and conducted experiments on this device.

At present, rice seeds are sorted in the existing seed production centers of the newly established "Cluster" enterprises and delivered to farmers to sow using the equipment available in the center [4-6].

However, because these methods and equipment are not sufficiently organized, they do not fully meet the agro-technical requirements for rice seeds prepared for sowing. It is known from scientific sources that electric field sorting of rice seeds is fully suitable for the

${ }^{*}$ Corresponding author: maxbubachariyeva@mail.ru 
preparation of high quality, biological properties close to each other, high germination rate, and potential yield in laboratory and field conditions [3].

\section{Methods}

Scientific research in this area has shown that the quality of rice seeds and rice products, their electrical resistance, electrical strength, and the angle of separation into fractions are the main factors in determining the quality of rice seeds directly into fractions. on the device(Figure 1) [6-8].

Schematic diagram of the experimental laboratory copy of the rice seed sorting device (a) and working body (b):
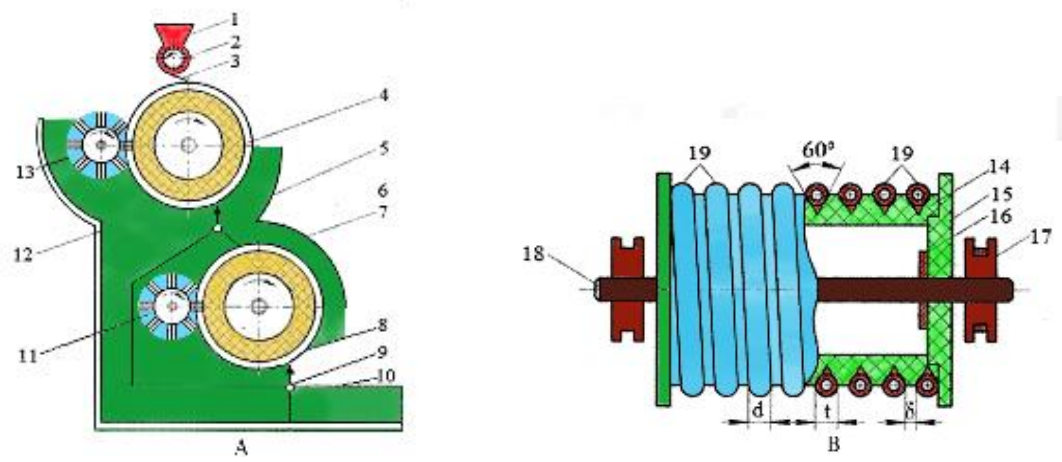

Fig. 1. Schematic diagram of the experimental laboratory copy of the rice seed sorting device (a) and working body (b): 1 is loading bunker; Supplier 2; 3, 6 is sliding board; 4, 8 is working body; 5, 9 is division plane; 7, 12 is protective walls; 10 is receiving bunker; 11,13 are detachable brushes; 14 is polyethylene pipe; 15 are sided discs; 16 are flanges; 17 is current conductors; 18 is val; 19 are electrodes with opposite signals.

The measurement of electrical resistance is important when sorting rice seeds in a sorting device "Dielectric." When studying the surface resistance and volume resistance of rice seeds, the shape of the working body made of dielectric material (in the form of cylinders, tubes, prisms, and other shapes), it is known from scientific studies that it is not suitable for rice seeds obtained separately $[9,10]$.

With this in mind, we created a special device to measure the total resistance of rice seeds (Figure 2).

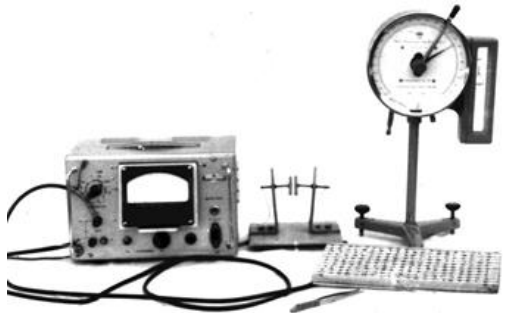

a)

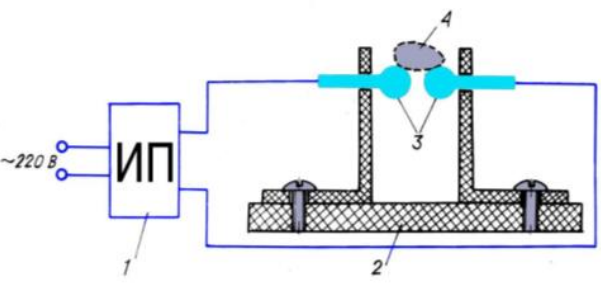

b)

Fig. 2. Schematic and general view of the device for measuring the electrical resistance of rice seeds. a) general view b) scheme. 1 is measuring instrument ES-3, 2 is dielectric base, 3 are parallel electrodes, 4 are rice seeds.

The parallel electrode is fixed, connected to each other, to a shielded conductor, using a measuring instrument ES-3. Rice seed 4, the electrical resistance of which is unknown, is 
placed on the electrodes, and a high voltage is applied; from the ES-3 instrument, the rice seed resistance reading is recorded for each rice seed from the resistance scale. From the values found, we see the relationship between the electrical resistance and mass of the rice seed, the variation distribution graph of the electrical resistance $f=f(R)$ (Figure 3).

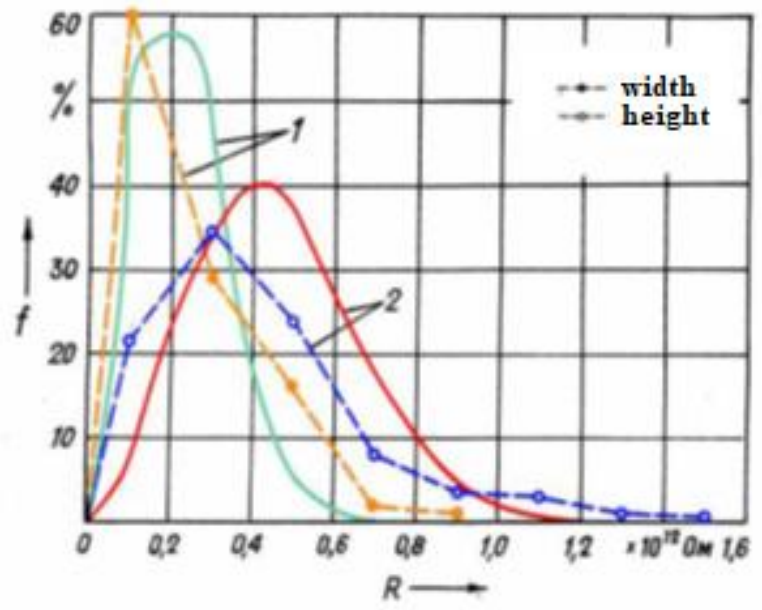

Fig. 3. Graph of variational distribution of electrical resistance of rice seeds.

In our next experiment, we created a device shown in Figure 4 to measure the separation angle of the rice seed from the surface of the working drum, conducted the experiments, and obtained the following results [11-13].

It is known from scientific research that when rice seed sorting is carried out in a "Dielectric" drum sorter, while other parameters are constant, a graph of the relationship between the separation angle $(\alpha)$ and the voltage applied to the electrodes (U) is shown (Figure 4).

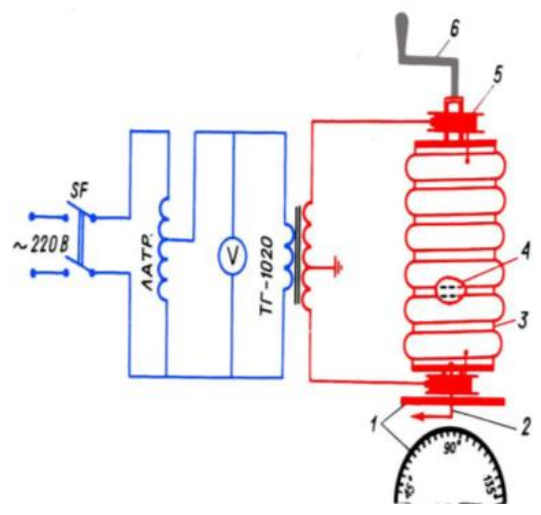

a)

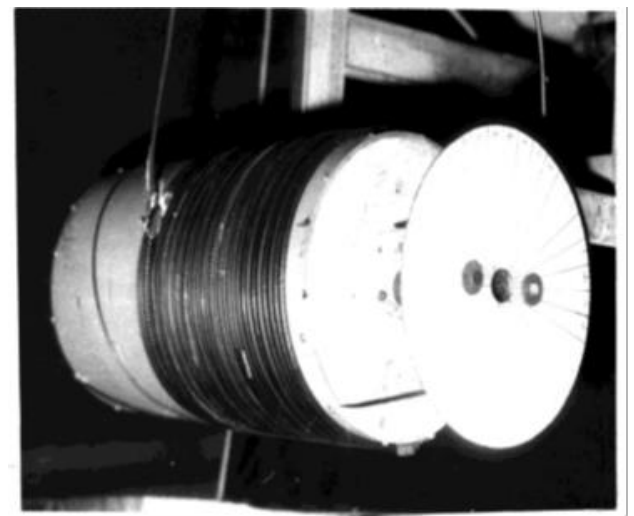

b)

Fig. 4. Schematic (a) and (b) of the seed separation angle measuring device; 1 is disc scale, 2 is indicator, 3 is dielectric drum, 4 is seed, 5 is connecting rod, 6 is handle. 


\section{Results and Discussion}

To conduct the experiment, an arbitrarily obtained rice seed is placed on the surface of the drum and slowly turned into a working body using a handle; we record the value from the indicator scale. The rotational frequency of the drum $\left(1 \mathrm{~min}^{-1}\right)$ is $\mathrm{F}_{\min }$; for a rice seed with a large mass, the centrifugal force is $1 \%$, let its gravitational force be $\mathrm{G}$.

We performed this experiment by applying a high voltage to the electrode, and when no voltage was applied, we performed the experiments at $U=750,1000,1250$, and $1500 \mathrm{~V}$ and saw the following connection graph between $\alpha=\mathrm{f}(\mathrm{U})$ (Figure 5).
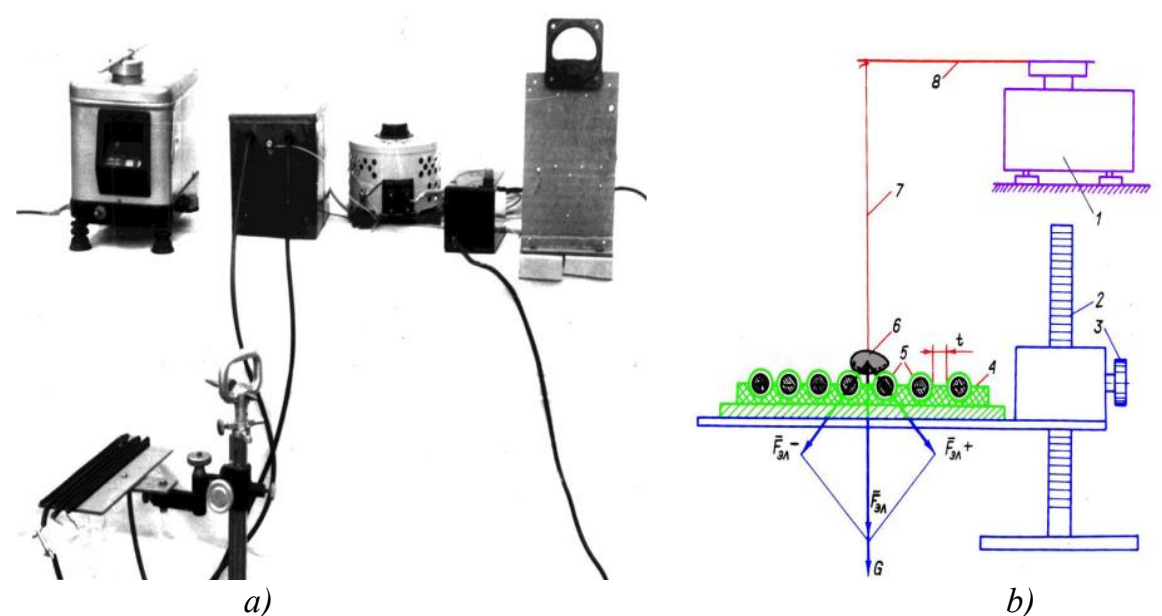

b)

Fig. 5. Schematic diagram of the electric power acting on the rice seed located on the surface of the electrode with a bifilar tube (a) and (b) is an overview of the device.

In the next stage of experiments, it was observed that the angle of separation of rice seeds of different masses on the surface of the rotating drum is directly related to the value of the high voltage applied to the rotating working body electrode. That is, as the value of the voltage increases, the angle also increases for rice seeds of different masses. For example, if the value of the high voltage is $\mathrm{U}=750 \mathrm{~V}$, then $\mathrm{m}=29,18 \mathrm{mg}$, then the angle $\alpha$ $=84^{\circ}$ (line 1 ), if $\mathrm{m}=30,43 \mathrm{mg}$, then $\alpha=60^{\circ}$ (line 3) [15-17].

If the voltage is $\mathrm{U}=1000 \mathrm{~V}$, then $\alpha=130^{\circ}$ and $\alpha=73^{\circ}$. Separation angle for small rice seeds $(\mathrm{m}>50 \mathrm{mg})$, for rice seeds (line 1) and for rice seeds $(\mathrm{m}<50 \mathrm{mg})$ (line 2) for large rice seeds $(2,3,4$ lines) were not significantly different from each other (Figure 6) [14, 20, 21]. 


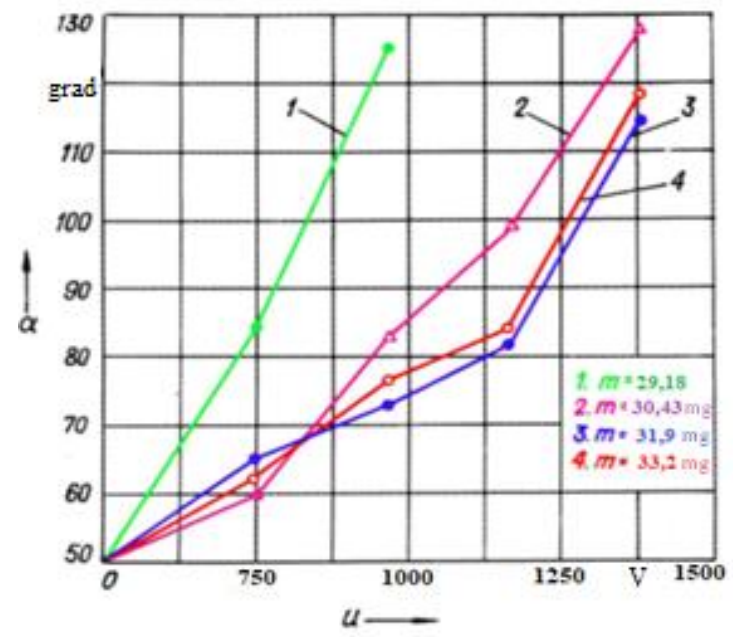

Fig. 6. Graph of the relationship between the angle of separation $(\alpha)$ of seeds of different masses and the voltage $(\mathrm{U})$ applied to the electrode.

This, in turn, led to a change in the voltage applied to the electrode, which led to a change in the separation angle of the rice seed, which resulted in the sowing of large and small mass rice seeds on the drum surface and the separation into waste fractions, resulting in a high-quality flat seedling $[18,19]$.

To determine the electric force acting on the rice seed on the surface of the bifilar coil electrode, the next experiment was to polarize when the rice seed fell between the electrodes on the rotating drum surface, the electric force and other forces acting on the seed as a result of the interaction, and the graph in Figure 7 [22-27].

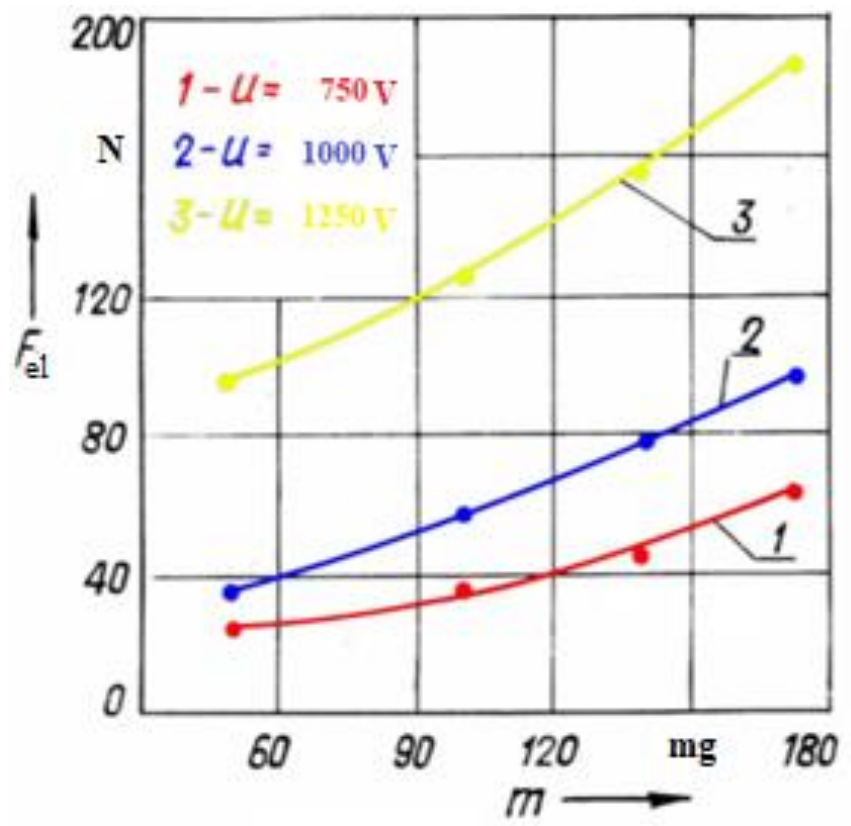

Fig. 7. Graph of dependence of traction electric force $\left(\mathrm{F}_{\mathrm{el}}\right)$ on seed mass $(\mathrm{m})$. 


\section{Conclusions}

Suppose we assume that the value of the mechanical forces in a fixed structure fixed working body does not change the studied rice seed. In that case, it will be possible to control the sorting process by changing the value of the voltage to change the value of the electric force.

The main purpose of the experiments was to create an industrial version of the "Dielectric" sorting device by studying the electrical resistance of the seed in preparation for sowing, the angle of separation from the surface of the rotating drum, and the electric force; these results are based on the basic parameters of the device.

\section{References}

1. Raximov X.R. Bolshe vnimaniya kachestvu posevnyx semyan, Xlopkovodstvo, 4(9), p 10. Moscow, (1980)

2. OST 2182.076, GOST 21820.4.76 and Oz. Dst.663: 2006 "Seed corn: Specifications. Tashkent. (2006)

3. Shoyimov P. Sorting opushennyx semyan xlopchatnika in barabannom dielectric separator: Avtoref. dis. Kand.texn.nauk, p 17. Tashkent, (1995)

4. Yusubaliev A., Shoyimov P., Murodov B.B. "Dielectric sorting of seeds equipment (ChDSU-2), Development of Science and Technology", Scientific and Technical Journal, 5, pp 134-137. Bukhara, (2019)

5. Shoyimov P. Sorting of fluffy cottonseeds in a drum dielectric separator. Abstract of dissertation of candidate of technical sciences. Tashkent, p. 17. (1995)

6. Yusubaliev A., Shoyimov P. Dielectric separator of cottonseeds, Proceedings of UzNSRIME. 34, pp. 15-154. (1992).

7. Khafizov II, Komil Gafforov, Bakhodir Oblokulov, Aziz Azimov, Elimination of energy losses in pumping installations by means variable frequency drive, International Engineering Journal For Research \& Development, 5, (3), (2020).

8. Khafizov II, Komil Gafforov, Muxammedov Sh., Jurakulov A, Energy saving when using a variable frequency drive in pump installations, Journal of Critical Reviews, (2020)

9. Khafizov I.I., Khaitov B.B. The investigation of ions implantation processes into a single-crystal GaAs (001) in order to increase the efficiency of the solar cells, MODERN SCIENCE International scientific journal №02, 2017, Founder and publisher: "Strategic Studies Institute" LLC., pp.43-46 Moscow, (2017),

10. Khafizov I.I., Gafforov K.K. Application and prospects of variable frequency means in electric drives of pumping units, International scientific-practical electronic journal «MOYA PROFESSIONALNAYA KARERA» (ISSN 2658-7998, dogorov s Elibrary №284-07 / 2019), (2020).

11. Khafizov I.I., Khafizov X.I. Modeling the introduction of ions into single-crystal gaas (001) to create $p$ - $n$ junctions in order to increase the efficiency of solar cells, MOLODEJNYY ISSLEDOVATELSKIY POTENTSIAL, Sbornik statey II Mezhdunarodnogo nauchno-issledovatelskogo konkursa, sostoyavshegosya January 11. v g. Petrozavodsk, st, pp 105-111

12. Amirov S.F., Babanazarova N.K., Research of dynamic operating mode of wide range current transformer, «European applied sciences». 1, pp. 52-54. Germany, (2016)

13. Amirov S.F., Babanazarova N.K., Magnetic circuit analysis of current transformer with multiple-turn core, «European applied sciences». 7, pp. 23-26. Germany, (2016). 
14. Amirov S.F., Rustamov D.Sh., Babanazarova N.K., Research of dynamic characteristics of electromagnetic current transducer, «European science review», Vienna, 3-4, pp. 95-98, (2019)

15. Amirov S.F., Babanazarova N.K. Distantsionnye elektromagnitnye preobrazovateli bolshix peremennyx tokov. «UNIVERSUM», Scientific journal. 4 (73). Moscow, (2020).

16. Babanazarova N.K., Charyeva M.R.Voprosy preobrazovaniya bolshix peremennyx tokov. «UNIVERSUM», Scientific journal. Moscow, 5 (75).

17. Jumaboev S.X., Babanazarova N.K. Distantsionnyy elektromagnitnyy preobrazovatel bolshix tokov trexfaznyx vysokovoltnyx liniy, II Mezhdunarodnaya nauchnotehnicheskaya konferentsiya, Ufa, Russia, (2019). pp. 131 -136. (2019)

18. Amirov S.F., Babanazarova N.K., Discrete Current Measuring Transformers, SHEMICAL TECHNOLOGY. CONTROL AND MANAGEMENT, International scientific and technical journal, № 5-6 (95-96), pp.53-57, (2020)

19. Muzaffarov F. F., Jo'raev M. K., Rustamov S. Sh., Gafurov M. O., Raxmatova M. U., Badriddinov R. K. "On the distribution of mds and magnetic currents in the transformer" star-double zigzag with zero conduction "'" XXV International Scientific-Practical conference "EurasiaScience" PART I Research and Publishing Center "Actualnots.RF", Moscow, Russia (2019)

20. Jo'raev M.Q, Muzaffarov F.F, Rustamov S.Sh. "Transparent Surface Lens Of LowTemperature Solar Devices" The American Journal of Applied Sciences, 2 (10), pp 145-149

21. Rakhmonov S., Umurzakov U., Rakhmonov K., Bozarov I., Karamatov O. Land use and land cover change in Khorezm, Uzbekistan. E3S Web of Conferences, 227, 01002, (2021)

22. Umurzakov U., Mamatov F., Aldoshin N., Mirzaev B. Exploration of tillage technologies in the Republic of Uzbekistan, IOP Conference Series, Earth and Environmental Science, 614(1), 012168, (2020)

23. Umurzakov U., and Djuraev B. Prediction of prices for agricultural products through markov chain model, International Journal of Psychosocial Rehabilitation, 24(3), pp. 293-303, (2020)

24. Umurzakov U., Mirzaev B., Salahodjaev R., Isaeva A., and Tosheva S. Energy consumption and economic growth: Evidence from post-communist countries. International Journal of Energy Economics and Policy, 10(6), pp. 59-65, (2020)

25. Aslanova G.N., Nematov L.A., Akhmedov A.A., Latipov S.T. "Calculation of reliability indicators of power supply systems of consumers» RSES 2019. E3S Web of Conferences 139, 01037. (2019)

26. Ershov M.S., Jalilov R.B., Shayimova S.P., Choriyev A.I. «Modeling of reliability of power supply systems with autonomous energy source» RSES 2019. E3S Web of Conferences 139, 01036. (2019).

27. Charyeva Makhbuba Rizakulyevna. Alternative Energy Sources. The American Journal of Applied Sciences, 3(01), 58-68. (2021) 